\begin{tabular}{|l|l|l||}
\hline \multicolumn{2}{|c|}{ PublisherInfo } \\
\hline \hline PublisherName & $:$ & BioMed Central \\
\hline \hline PublisherLocation & $:$ & London \\
\hline \hline PublisherImprintName & $:$ & BioMed Central \\
\hline \hline
\end{tabular}

\title{
Mitochondrial DNA insertions
}

\begin{tabular}{|l|l|l||}
\hline \multicolumn{2}{|c|}{ ArticleInfo } \\
\hline \hline ArticleID & $:$ & 4057 \\
\hline \hline ArticleDOI & $:$ & $10.1186 /$ gb-spotlight-20010420-01 \\
\hline \hline ArticleCitationID & $:$ & spotlight-20010420-01 \\
\hline \hline ArticleSequenceNumber & $:$ & 128 \\
\hline \hline ArticleCategory & $:$ & Research news \\
\hline \hline ArticleFirstPage & $:$ & 1 \\
\hline \hline ArticleLastPage & $:$ & 2 \\
\hline \hline & & RegistrationDate : 2001-04-20 \\
ArticleHistory & $:$ & OnlineDate $\quad$ 2001-04-20 \\
\hline \hline ArticleCopyright & $:$ & BioMed Central Ltd2001 \\
\hline \hline ArticleGrants & $:$ & \\
\hline \hline ArticleContext & $:$ & 130592211 \\
\hline \hline
\end{tabular}




\section{Jonathan B Weitzman}

Email: jonathanweitzman@hotmail.com

There is evidence for substantial transfer of mitochondrial DNA (mtDNA) to the nuclear genome in plants. Analysis of the recently completed Arabidopsis thalianagenome sequence indicated a mtDNA insertion of 270 kilobases $(\mathrm{kb})$, larger than previously described mitochondria-to-nuclear DNA insertions. In the April 24 Proceedings of the National Academy of Sciences, Stupar et al. present a detailed cytological characterization of the mtDNA insertion in chromosome 2 of A. thaliana (Proc Natl Acad Sci USA 2001, 98:5099-5103). Using fiber-fluorescence in situ hybridization (fiber-FISH) they show that the insertion is about $620 \mathrm{~kb}$, or 2.3 times the size estimated in original measurements. The authors suggest that the complex and repetitive nature of inserted mtDNA can result in misleading estimates of insert length, and that fiber-FISH offers a high-resolution tool for genome analysis.

\section{References}

1. The mitochondrial gene encoding ribosomal protein $\mathrm{S} 12$ has been translocated to the nuclear genome in Oenothera.

2. Sequence and analysis of chromosome 2 of the plant Arabidopsis thaliana.

3. Proceedings of the National Academy of Sciences, [http://www.pnas.org/] 